\title{
Phylogeography of the Italian vairone (Telestes muticellus, Bonaparte 1837) inferred by microsatellite markers: evolutionary history of a freshwater fish species with a restricted and fragmented distribution
}

\author{
Flavio Marchetto ${ }^{1,2}$, Serena Zaccara*1, Frauke M Muenzel2 ${ }^{2}$ and Walter Salzburger*2
}

\begin{abstract}
Background: Owing to its independence from the main Central European drainage systems, the Italian freshwater fauna is characterized by a high degree of endemicity. Three main ichthyogeographic districts have been proposed in Italy. Yet, the validity of these regions has not been confirmed by phylogenetic and population genetic analyses and a phylogeographic scenario for Italy's primary freshwater fish fauna is still lacking. Here, we investigate the phylogeography of the Italian vairone (Telestes muticellus).

Results: We sampled 38 populations representing the species' entire distribution range and covering all relevant drainage systems, and genotyped 509 individuals at eight variable microsatellite loci. Applying various population genetic analyses, we identify five distinct groups of populations that are only partly in agreement with the proposed ichthyogeographic districts. Our group I, which is formed by specimens from Veneto and the Po River system draining into the Adriatic Sea, corresponds to the Padano-Venetian ichthyogeographic district (PV), except for two Middle Adriatic drainages, which we identify as a separate group (III). The Tuscano-Latium district (TL) is equivalent to our group V. A more complex picture emerges for the Ligurian drainages: populations from Central Liguria belong to group I, while populations from West (group II) and East Liguria (group IV) form their own groups, albeit with affinities to PV and $\mathrm{TL}$, respectively.

Conclusions: We propose a phylogeographic scenario for T. muticellus in which an initial T. muticellus stock became isolated from the 'Alpine' clade and survived the various glaciation cycles in several refugia. These were situated in the Upper Adriatic (groups I and II), the Middle Adriatic (group III), (East) Liguria (group IV) and Tuscano-Latium (group V). The population structure in the vairone is, in principal, in agreement with the two main ichthyogeographic districts (PV and TL), except for the two populations in the Middle Adriatic, which we identify as additional major "district".
\end{abstract}

\section{Background}

It is now well established that the Quaternary ice ages were among the main contributing factors shaping the present distribution of species and of populations within species [1-3]. At least in the temperate and polar zones,

*Correspondence: serena.zaccara@uninsubria.it, walter.salzburger@unibas.ch

1 Department of Biotechnology and Molecular Sciences, University of Insubria, via Dunant 3, 21100 Varese, Italy

2 Zoological Institute, University of Basel, Vesalgasse 1, 4055 Basel, Switzerland Full list of author information is available at the end of the article the cyclic climate changes caused a shift of biomes in a North-South direction and repeatedly produced the situation that different populations belonging to the same species were separated by geographic barriers [4]. Species inhabiting North America and Europe, the two continents that were covered by the most extensive glacial sheets, were influenced in different ways with regard to the impact of ice ages on migration: in North America the main geographical barriers had the same orientation as the biomes' shift, while in Europe, due its complex geog- 
raphy, strong barriers to migration existed. The Mediterranean Sea, for example, limited migration towards North Africa so that many taxa were restricted to the large southern European peninsulas - the Iberian, the Balkan and the Italian - during the maximal glacial expansions. In addition, the most important mountain chains bordering these glacial refugia limited areal reexpansion towards Central and northern Europe during the interglacial periods. The combination of these two geographical features isolated populations of various taxa, thereby triggering genetic diversification and (allopatric) speciation [2].

Phylogeography, i.e. the integration of the phylogenetic inferences and/or population genetic relationships among individuals or taxa on one hand, and their geographic distribution on the other hand [5], offers the means to reconstruct the historical processes that triggered the geographic distribution of biodiversity. In this context, freshwater fishes constitute an important model group because their dispersion, diversification and speciation are strictly related to the processes that shaped the landmass and the hydrogeographic systems, which they inhabit [6,7]. There are only few ways by which a primary freshwater fish can reach a new river basin: by river capture [8], by downstream river confluence when the sea level is lowered [9], by dispersal over the sea under lower salinity conditions ("lago-mare" phase; [10]), or by lakes formed during the retreat of glaciers [6].

The Italian peninsula - isolated from continental Europe by the Alps, the highest mountain chain with an East-West orientation - hosts a relatively high number of endemic freshwater taxa [10-13]. Its independence from the main Central European drainage systems Danube, Rhine and Rhône favored this high degree of endemicity. The Italian hydrographic structure is largely influenced by the North-South orientated Apennine barrier, which modulated the allopatric distribution and the diversification of various freshwater taxa [10]. Based on the distribution of cyprinid fishes, three main ichthyogeographic districts were identified [10]: (i) the Padano-Venetian district (PV) including basins from the Vomano river to the Krka river, which all drain into the Adriatic Sea; (ii) the Tuscano-Latium district (TL) from the Serchio river to the Tevere river, which drain into the middle Tyrrhenian Sea; and (iii) the South Italy district (SI) (Fig. 1). Despite the importance of the Italian peninsula as major glacial refugia in general and its role in shaping the distribution and diversity of the Central European freshwater fish fauna in particular, little is known about the phylogeography of freshwater fishes in that area, and detailed studies based on molecular markers and including specimens from all relevant river basins are lacking. Therefore, limited knowledge on the recent evolution of the Italian hydrographic systems at regional and local scale is avail- able, and a clear-cut picture of the more recent changes in the Italian hydrographic structure is lacking.

The vairone is a primary freshwater fish belonging to the family Cyprinidae, it is distributed in and around the Alps, and represents a good candidate for phylogeographic inference [14-17]. The taxonomic status and the generic assignment of the vairone are, however, under debate. Some authors stick to its original genus name Leuciscus [14-16], while others assign it to Telestes based on its position in the phylogeny of European cyprinids [18-21]. Phylogenetic analyses based on mitochondrial DNA (mtDNA) revealed the existence of two main lineages within the vairone, $T$. souffia and T. muticellus (note that T. souffia is listed as subspecies of Telestes souffia by some authors $[14,15]$, while being granted species rank by others $[16,17,21])$. In the present study, we use the latter assignment, i.e. Telestes muticellus, because of its great genetic distance ( $>5 \%$ in mtDNA) to the 'Alpine' clade [15].

The vairone inhabits cold running waters with high levels of dissolved oxygen. Its diet primarily consists of benthic invertebrates and, occasionally, of algae and plant remains. It exhibits a gregarious behavior, and the breeding period lasts from May to August; egg deposition takes place in the nocturnal hours on gravel, and larvae hatch after six days. Sexual maturity is reached after two to three years. The vairone is included in the red list of threatened species by the International Union for Conservation of Nature (IUCN) [22] as "Least Concern", and is listed in the Appendix III of the Bern Convention. In the last years, the Italian vairone has suffered a decrease in distribution range and in population size due to habitat degradation.

Here, we use the endemic Italian vairone (Telestes muticellus) as a model to assess the phylogeographic history of primary freshwater fishes in Italy [23]. This species appears highly suitable for this purpose, as it has a fragmented distribution that is restricted to Central and northern Italy and, there, covers the two main ichthyogeographic districts (PV and TL). Previous phylogeographic studies based on mtDNA indicated a population genetic structure largely in agreement with these ichthyogeographic districts but, at the same time, highlighted a more complex distribution of haplotypes in the Tyrrhenian basins of Liguria, where the freshwater fauna is considered introduced $[10,24,17]$. However, these studies were based on relatively small sets of populations only, and the results have not been corroborated with nuclear DNA markers. In this study, we used a sample of 38 populations $(\mathrm{N}=509)$ covering the entire distribution range of T. muticellus and representing all relevant drainage systems, and applied eight microsatellite markers to infer the phylogeographic history of this species. Specifically, we were interested in the question whether populations 

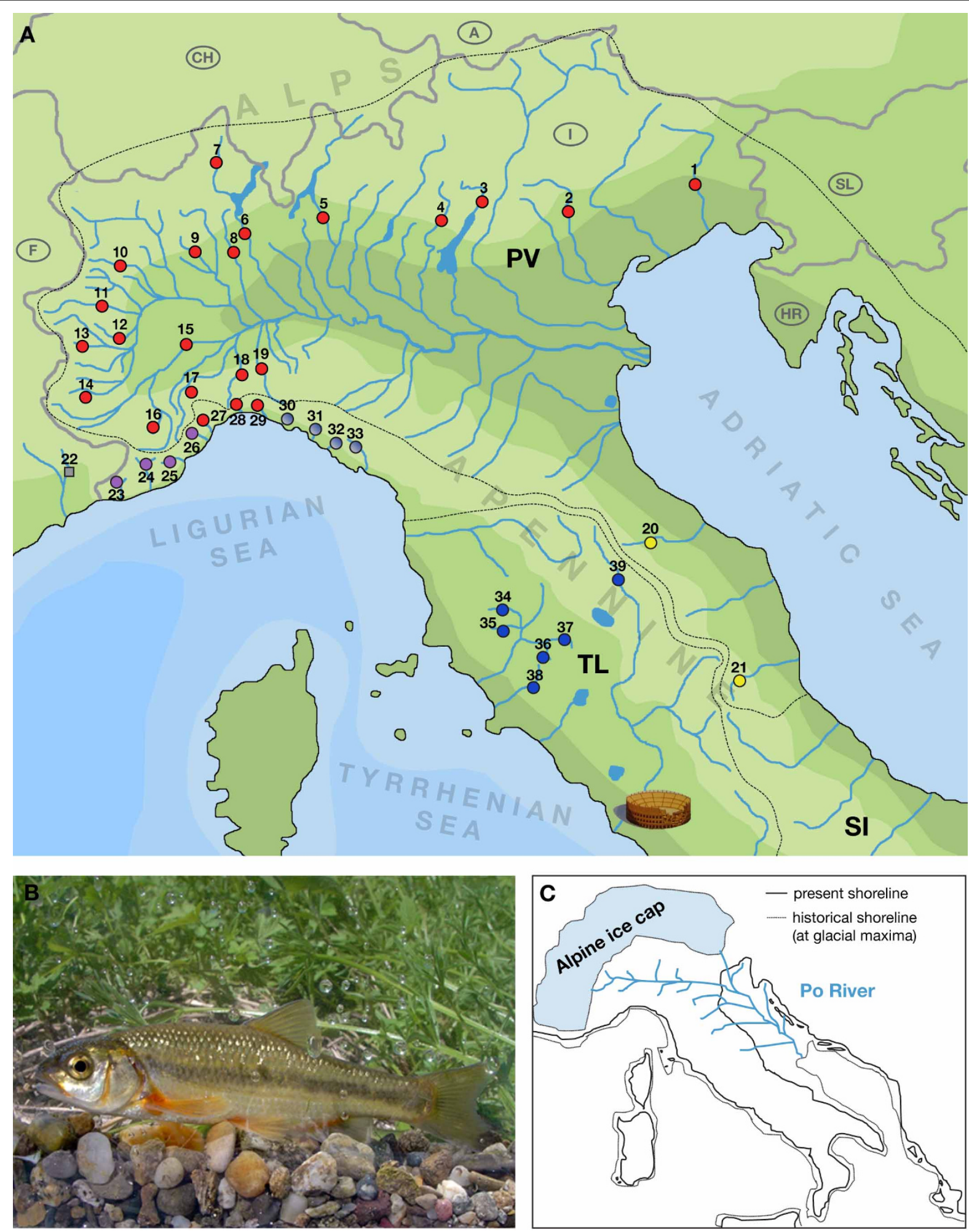

Figure 1 The vairone in Italy. (a) Map of northern and Central Italy showing the main river systems, the ichthyogeographic districts and the sampling sites. Numbers (and colors) of the sampling sites correspond to Table 1 and Fig. 2. Note that population 22 consisted of specimens of Telestes souffia, the sister species to T. muticellus, and was excluded from some of the analyses. (b) The Italian vairone (Telestes muticellus). (c) During glacial maxima, the Alps were covered by an ice cap and sea levels were markedly lowered; the estuary of the Po River system, which also included rivers that today directly drain into the Adriatic Sea, was situated at the Middle Adriatic pitch. PV...Padano-Venetian ichthyogeographic district; TL...Tuscano-Latium ichthyogeographic district; SI...South Italian ichthyogeographic district. 
of T. muticellus are structured according to the main ichthyogeographic districts that have been proposed on the basis of the distribution of cyprinid fish but without taking genetic information into account. We also aimed at identifying potential glacial refugia permitting vairone populations to outlive periods of maximal glacial extensions during Quaternary ice ages, as well as possible postglacial re-colonization routes. The "permeability" of major barriers (such as the Apennine) was of particular interest to us. Finally, by integrating our population genetic data, sea level fluctuations information and the bathymetric profiles of the Adriatic Sea and the Tyrrhenian Sea, we intended to reconstruct the ways by which vairone populations dispersed and to suggest the recent changes in the hydrographic pattern that allowed the dispersion of the vairone from one basin into another.

\section{Methods}

Sampling

A total of 509 individuals from 38 populations were sampled between 2002 and 2008 covering the entire distribution range of T. muticellus (Fig. 1, Table 1). We sampled between four and twenty individuals per population so that each of the drainage systems was represented by at least 20 individuals. Twenty-one populations belong to the Padano-Venetian ichthyogeographic district (pops. 1 - 21), six to the Tuscano-Latium district (pops. 34 - 39) and eleven to Ligurian basins (pops. 23 - 33) draining into the Tyrrhenian Sea. A single population of 15 individuals belonging to the subspecies T. souffia souffia from SouthEast France (pop. 22; Fig. 1, Table 1) was included in order to evaluate possible hybridization events with neighboring populations of T. muticellus (see [14,15]). All specimens were collected using electric fishing gear; a clip of the anal fin was preserved in $100 \%$ ethanol and stored at $4^{\circ} \mathrm{C}$ as DNA sample.

\section{Molecular analyses}

Total DNA was extracted using a standard extraction kit (DNeasy tissue kit, Qiagen, Valencia, CA, USA). All individuals were genotyped at eight highly informative microsatellite loci isolated for T. souffia (Lsou05, Lsou08, Lsou09, Lsou10, Lsou11, Lsou19, Lsou21, Lsou34; [25]). Microsatellites were amplified with fluorescently labeled forward primers (FAM, HEX and NED). Three different sets of markers were used such that all fragments could be separated within a single capillary without overlap and scored unambiguously. The first set included Lsou05, Lsou08 and Lsou19, the second set included Lsou10 and Lsou34, and the third set included Lsou09, Lsou11 and Lsou21. Polymerase chain reaction was carried out in 10 $\mu \mathrm{L}$ reaction volumes containing $5 \mu \mathrm{L}$ QIAGEN Multiplex PCR Master mix, $3 \mu \mathrm{L}$ dd $\mathrm{H}_{2} \mathrm{O}, 1 \mu \mathrm{L}$ DNA $(20 \mathrm{ng} / \mu \mathrm{L})$ and $1 \mu \mathrm{L}$ primer mix (2 pmol/ $\mu \mathrm{L}$ per primer) on a Veriti ther- mal cycler (Applied Biosystems). The PCR profile started with an initial denaturation step at $95^{\circ} \mathrm{C}$ for $15 \mathrm{~min}$, followed by 30 cycles of $30 \mathrm{~s}$ at $94^{\circ} \mathrm{C}, 90 \mathrm{~s}$ at $56^{\circ} \mathrm{C}, 90 \mathrm{~s}$ at $72^{\circ} \mathrm{C}$ and ended with a final extension of $10 \mathrm{~min}$ at $72^{\circ} \mathrm{C}$. Fragment lengths were determined with the internal size marker Genescan-500 ROX (Applied Biosystems) on an AB 3130 automated capillary sequencer (Applied Biosystems) and scored with GeneMapper (Applied Biosystems).

\section{Statistical analyses}

Allele binning was performed with TANDEM[26]. The software MSA[27] was used to determine mean microsatellite allele numbers $\left(\mathrm{A}_{\mathrm{N}}\right)$, observed heterozygosities $\left(\mathrm{H}_{\mathrm{o}}\right)$ and expected heterozygosities $\left(\mathrm{H}_{\mathrm{e}}\right)$ within populations. GENEPOP version 3.2a [28] was employed to estimate deviations from Hardy-Weinberg Equilibrium (HWE) across populations (within loci) and across loci (within populations) using the probability test, with 10000 dememorization steps, 100 batches and 5000 iterations per batch based on the approach by Guo and Thompso [29]. Computation of pair wise multilocus $\mathrm{F}_{\mathrm{ST}}$ values [30] among populations, as well as $R_{S T}$ and $F_{I S}$ values was performed using the software ARLEQUIN version 3.1 [31] with 1000 permutation and an allowing a level of missing data of 0.05 . Allele frequencies, a pair wise population matrix of Nei's genetic distance were computed by GENEALEX[32].

A neighbor joining (NJ; [33]) population tree was generated based on Cavalli-Sforza \& Edwards chord distances $\left(D_{\mathrm{C}}\right)$ [34], which were calculated in PHYLIP version 3.67 [35]. Following the recommendation of Van Dongen [36] with respect to relatively low numbers of loci, 10000 bootstrap pseudo-replicates were performed over individuals rather than loci. Bootstrap replicates were generated using the application SEQBOOT (available in PHYLIP package).

Factorial Correspondence Analysis (FCA, [37]), which displays the genetic similarity among samples in a threedimensional graphical space, and an assessment of the genetic variability in each population were undertaken using the software GENETIX version 4.02 [38]. STRUCTURE version 2.2 [39] was used to determine the population structure by Bayesian clustering analysis, with a burn-in of $5 \times 10^{4}$ and $10^{6}$ iterations, and not using prior population information. The most likely value for the number of populations $(K)$ was determined by the " $L(K)$ " method suggested by Evanno et al. [40], varying $K$ from a minimum of one to a maximum of 11 and always performing 10 runs for each value of $K$.

Hierarchical analysis of molecular variance (AMOVA), based on allele frequency information [41], was carried out using ARLEQUIN. Variance components were extracted for the $(i)$ among group, (ii) between sampling 
Table 1: Sampling locations of the T. muticellus (and T. souffia; pop. 22) populations analyzed in this study.

\begin{tabular}{|c|c|c|c|c|c|c|c|}
\hline Population & River & River basin & $\mathrm{n}^{\circ}$ individuals & District & Drainage & \multicolumn{2}{|c|}{ GPS coordinates } \\
\hline 1 & Tagliamento & Tagliamento & 14 & A & Venetian basins & $45^{\circ} 59^{\prime} \mathrm{N}$ & $12^{\circ} 54^{\prime} \mathrm{E}$ \\
\hline 2 & Bacchiglione & Bacchiglione & 20 & A & & $45^{\circ} 37^{\prime} \mathrm{N}$ & $11^{\circ} 26^{\prime} \mathrm{E}$ \\
\hline 3 & Sarca & Po & 8 & A & & $45^{\circ} 96^{\prime} \mathrm{N}$ & $10^{\circ} 92^{\prime} \mathrm{E}$ \\
\hline 4 & Chiese & Po & 4 & A & & $45^{\circ} 89^{\prime} \mathrm{N}$ & $10^{\circ} 60^{\prime} \mathrm{E}$ \\
\hline 5 & Adda & Po & 12 & $A$ & & $45^{\circ} 40^{\prime} \mathrm{N}$ & $09^{\circ} 49^{\prime} \mathrm{E}$ \\
\hline 6 & Ticino & Po & 12 & $A$ & & $45^{\circ} 40^{\prime} \mathrm{N}$ & $08^{\circ} 92^{\prime} \mathrm{E}$ \\
\hline 7 & Toce & Po & 15 & $A$ & & $46^{\circ} 07^{\prime} \mathrm{N}$ & $08^{\circ} 26^{\prime} \mathrm{E}$ \\
\hline 8 & Agogna & Po & 15 & A & & $45^{\circ} 69^{\prime} \mathrm{N}$ & $08^{\circ} 42^{\prime} \mathrm{E}$ \\
\hline 9 & Sesia & Po & 15 & A & & $45^{\circ} 57^{\prime} \mathrm{N}$ & $08^{\circ} 18^{\prime} \mathrm{E}$ \\
\hline 10 & Orco & Po & 15 & A & & $45^{\circ} 33^{\prime} \mathrm{N}$ & $07^{\circ} 72^{\prime} \mathrm{E}$ \\
\hline 11 & Dora Riparia & Po & 15 & A & Po basin & $45^{\circ} 08^{\prime} \mathrm{N}$ & $07^{\circ} 40^{\prime} \mathrm{E}$ \\
\hline 12 & Lemina & Po & 11 & $A$ & & $44^{\circ} 91^{\prime} \mathrm{N}$ & $07^{\circ} 31^{\prime} \mathrm{E}$ \\
\hline 13 & Pellice & Po & 13 & A & & $44^{\circ} 78^{\prime} \mathrm{N}$ & $07^{\circ} 51^{\prime} \mathrm{E}$ \\
\hline 14 & Maira & Po & 15 & $A$ & & $44^{\circ} 46^{\prime} \mathrm{N}$ & $07^{\circ} 37^{\prime} \mathrm{E}$ \\
\hline 15 & Vernetto & Po & 15 & A & & $44^{\circ} 99^{\prime} \mathrm{N}$ & $08^{\circ} 02^{\prime} \mathrm{E}$ \\
\hline 16 & S. Bernardo & Po & 12 & A & & $44^{\circ} 38^{\prime} \mathrm{N}$ & $07^{\circ} 91^{\prime} \mathrm{E}$ \\
\hline 17 & Bormida & Po & 15 & A & & $44^{\circ} 39^{\prime} \mathrm{N}$ & $08^{\circ} 21^{\prime} \mathrm{E}$ \\
\hline 18 & Orba & Po & 15 & A & & $44^{\circ} 62^{\prime} \mathrm{N}$ & $08^{\circ} 60^{\prime} \mathrm{E}$ \\
\hline 19 & Scrivia & Po & 15 & $A$ & & $44^{\circ} 80^{\prime} \mathrm{N}$ & $08^{\circ} 97^{\prime} \mathrm{E}$ \\
\hline 20 & Tesino & Tesino & 10 & A & Middle Adriatic & $42^{\circ} 57^{\prime} \mathrm{N}$ & $13^{\circ} 38^{\prime} \mathrm{E}$ \\
\hline 21 & Burano & Burano & 10 & A & & $43^{\circ} 34^{\prime} \mathrm{N}$ & $12^{\circ} 40^{\prime} \mathrm{E}$ \\
\hline 22 & Peillon & Peillon & 15 & SF & France & $43^{\circ} 46^{\prime} \mathrm{N}$ & $07^{\circ} 22^{\prime} \mathrm{E}$ \\
\hline 23 & Barbaira & Nervia & 15 & L & West Liguria & $43^{\circ} 53^{\prime} \mathrm{N}$ & $07^{\circ} 38^{\prime} \mathrm{E}$ \\
\hline 24 & Oxentina & Argentina & 15 & L & & $43^{\circ} 91 ' \mathrm{~N}$ & $07^{\circ} 85^{\prime} \mathrm{E}$ \\
\hline 25 & Arroscia & Centa & 15 & L & & $44^{\circ} 03^{\prime} \mathrm{N}$ & $07^{\circ} 58^{\prime} \mathrm{E}$ \\
\hline 26 & Barelli & Sciusa & 15 & L & & $44^{\circ} 23^{\prime} \mathrm{N}$ & $08^{\circ} 36^{\prime} \mathrm{E}$ \\
\hline 27 & Trexenda & Quiliano & 15 & L & Central Liguria & $44^{\circ} 17^{\prime} \mathrm{N}$ & $08^{\circ} 25^{\prime} \mathrm{E}$ \\
\hline 28 & Lerone & Lerone & 15 & L & & $44^{\circ} 23^{\prime} \mathrm{N}$ & $08^{\circ} 39^{\prime} \mathrm{E}$ \\
\hline 29 & Sardorella & Polcevera & 15 & L & & $44^{\circ} 29^{\prime} \mathrm{N}$ & $08^{\circ} 54^{\prime} \mathrm{E}$ \\
\hline 30 & Gentile & Gentile & 15 & L & East Liguria & $44^{\circ} 35^{\prime} \mathrm{N}$ & $09^{\circ} 16^{\prime} \mathrm{E}$ \\
\hline 31 & Sturla & Entella & 15 & L & & $44^{\circ} 23^{\prime} \mathrm{N}$ & $09^{\circ} 22^{\prime} \mathrm{E}$ \\
\hline 32 & Di Piazza & Deiva & 15 & L & & $44^{\circ} 22^{\prime} \mathrm{N}$ & $09^{\circ} 52^{\prime} \mathrm{E}$ \\
\hline 33 & Graveglia & Magra & 15 & L & & $44^{\circ} 09^{\prime} \mathrm{N}$ & $09^{\circ} 46^{\prime} \mathrm{E}$ \\
\hline 34 & Merse & Ombrone & 10 & $\mathrm{~T}$ & Tuscano-Latium & $43^{\circ} 14^{\prime} \mathrm{N}$ & $11^{\circ} 18^{\prime} \mathrm{E}$ \\
\hline 35 & Farma & Ombrone & 11 & $\mathrm{~T}$ & & $43^{\circ} 07^{\prime} \mathrm{N}$ & $11^{\circ} 26^{\prime} \mathrm{E}$ \\
\hline
\end{tabular}


Table 1: Sampling locations of the T. muticellus (and T. souffia; pop. 22) populations analyzed in this study. (Continued)

\begin{tabular}{|c|c|c|c|c|c|c|}
\hline 36 & Zancona & Ombrone & 15 & $T$ & $42^{\circ} 89^{\prime} \mathrm{N}$ & $11^{\circ} 54^{\prime} \mathrm{E}$ \\
\hline 37 & Ente & Ombrone & 10 & $\mathrm{~T}$ & $42^{\circ} 87^{\prime} \mathrm{N}$ & $11^{\circ} 54^{\prime} \mathrm{E}$ \\
\hline 38 & Albegna & Albegna & 4 & $\mathrm{~T}$ & $42^{\circ} 79^{\prime} \mathrm{N}$ & $11^{\circ} 51^{\prime} \mathrm{E}$ \\
\hline 39 & Tevere & Tevere & 18 & $\mathrm{~T}$ & $43^{\circ} 33^{\prime} \mathrm{N}$ & $12^{\circ} 07^{\prime} \mathrm{E}$ \\
\hline
\end{tabular}

The population number, river, river basin, number of individuals analyzed, the drainage system ("Drainage"), and the GPS coordinates of the sampling sites are given for each population. $\mathrm{A}=$ Adriatic basins; $\mathrm{SF}=$ South France; $\mathrm{L}=$ Ligurian basins; $\mathrm{T}=$ Tuscany basins.

sites within groups, and (iii) within sampling sites hierarchical levels. The populations were partitioned into groups according to their geography and following the outcomes of the pair wise multilocus $\mathrm{F}_{\mathrm{ST}}$ calculations, the FCA, the NJ tree and the Bayesian clustering analysis.

\section{Results}

Two of the microsatellite markers could not be successfully amplified in a small number of populations and were coded as missing data for the subsequent analyses: Lsou09 in populations 20 and 21, and Lsou11 in populations 20, 21, 22 and 26 (Additional file 1). All eight microsatellite loci were polymorphic, the number of alleles ranged from 9 to 17 at any single locus (mean 13.4). Mean expected heterozygosity per population ranged from 0.12 (s. d. 0.27 , pop. 38) to 0.6 (s. d. 0.21, pop. 3), and averaged 0.45 across all loci and populations. In general, the differences between expected and observed heterozygosities were low, ranging from 0 to 0.16 (mean 0.05) (see Additional file 1 for more details).

Significant departures from Hardy-Weinberg equilibrium (HWE) were observed in a number of populations and mainly in two loci, LsouO9 and Lsou11. This was most likely due to problems with the amplification of these loci in a small subset of samples (see above), which resulted in missing data in the evaluation of the departure from HWE. In the remaining loci the departures from HWE were due to an excess of homozygosity (Additional file 1).

$\mathrm{F}_{\mathrm{ST}}$ within loci and among populations were highest for Lsou10 (0.46), Lsou11 (0.5) and Lsou34 (0.4) (Additional file 2). Allele frequencies of all populations belonging to the Tuscano-Latium district showed a genetic pattern different from the other populations (Additional file 3). Populations from middle Adriatic (20 and 21) had characteristic allelic patterns in LsouO8 and Lsou21, while population 22 , constituted by $T$. souffia, was characterized by a private allelic pattern in loci Lsou05, Lsou09, Lsou19 and Lsou34.

Nei's distances among populations also indicate the great difference between the single population of $T$. souffia souffia and the populations of T. muticellus. Six principal groups of populations were recovered by $\mathrm{F}_{\mathrm{ST}}$ and $\mathrm{R}_{\mathrm{ST}}$ (Additional file 2) and Nei's distance (not shown): (i) the largest group included the specimens from the Venetian basins (pops. 1 and 2), the Po basin (pops. 3 to 19) plus the populations of Central Liguria (pops. 27, 28 and 29); (ii) a second group included two populations from West Liguria (pops. 23 and 24), which showed the lowest Nei's distance to populations from the opposite side of Apennine chain (pops. 15, 16 and 17) belonging to the Padano-Venetian district; (iii) the third group included specimens from middle Adriatic and showed large distances to all the others populations; (iv) individuals from Tuscano-Latium district form the fourth group (pops. 34 to 39); (v) individuals from East Liguria (pops. 30 to 33), which showed the smallest distance to populations of Tuscany, formed another group. The remaining two populations from Western Liguria (pops. 25 and 26) showed $\mathrm{F}_{\mathrm{ST}}$ and Nei's distance values intermediate between the Padano-Venetian populations and the other two Western Ligurian populations (pops. 23 and 24); (vi) the last group is equivalent to population 22 ( $T$. souffia souffia) and was excluded from the further analyses - also, because there was no sign of introgression with neighboring T. muticellus populations in a STRUCTURE analysis.

Because of the unsuccessful amplification of two loci in a few populations, two NJ trees were constructed, one with all populations without the two not amplified loci (Fig. 2a), and one with all loci without the populations with missing amplifications (not shown). The general topology of the two trees was in agreement and in congruence with the pattern of the observed $\mathrm{F}_{\mathrm{ST}}$ values among populations. Four main groups were recovered: $(i)$ the populations of the Padano-Venetian district (pops. 1 to 19) plus Central Liguria (pops. 27 to 29) and including a clade formed by the populations from Western Liguria (pops. 23 to 26); (ii) the two populations from the Middle Adriatic (pops. 20 and 21); (iii) populations from East Liguria (pops. 30 to 33); and (iv) populations from the Tuscano-Latium district (pops. 34 to 39). These clades were supported by high bootstrap values (Fig. 2a).

In the FCA plot of the entire data set, three main clusters of individuals were resolved: $(i)$ the Tuscano-Latium and East Ligurian populations; (ii) the populations from the Middle Adriatic; and (iii) populations belonging to the Po basin, the Venetian basins, and the West and Central Ligurian basins (Additional file 4a). The first three 


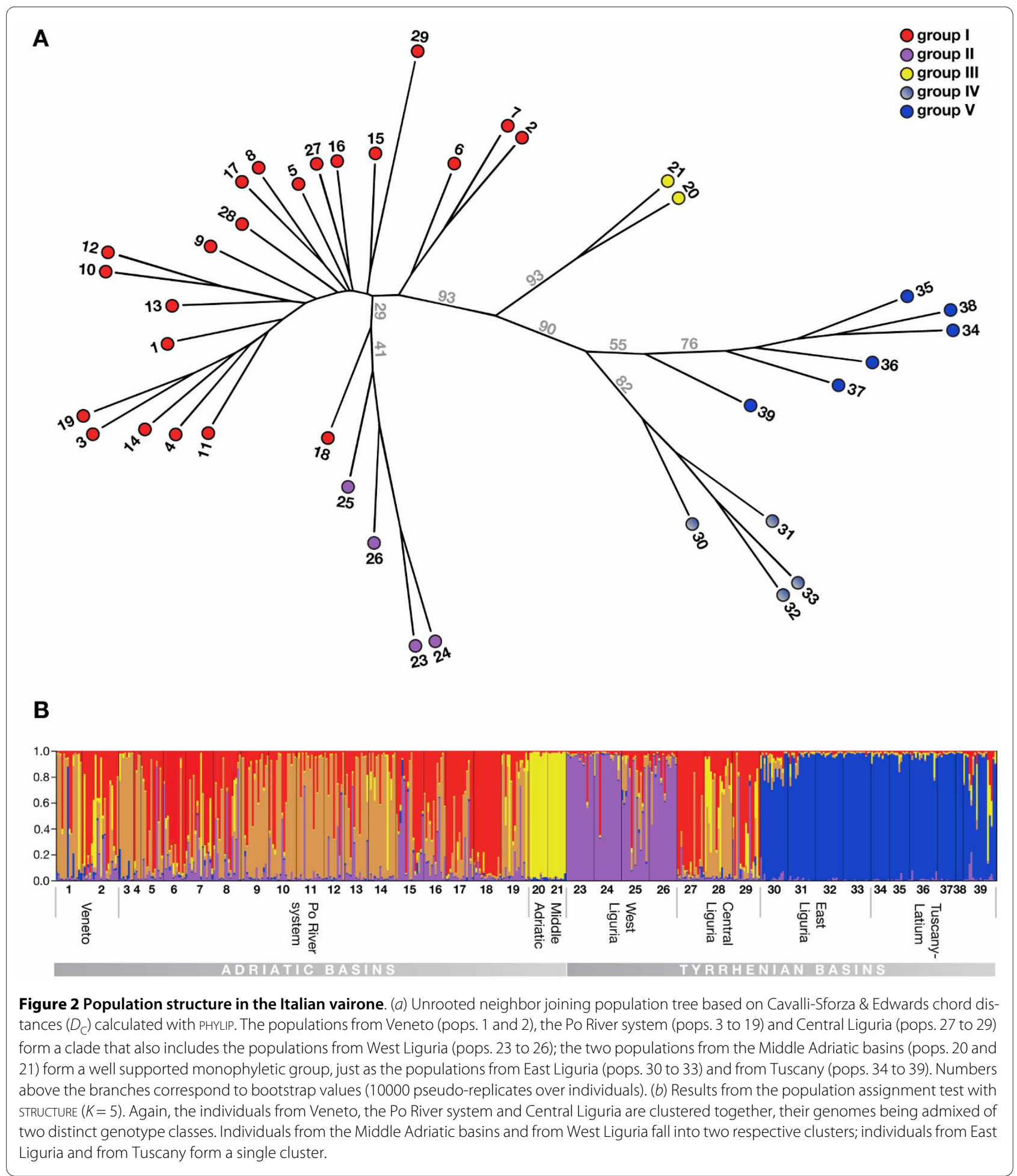

axes explained $11.74 \%$ of the total genetic variance. We then divided the data set according to the two sea catchments. The FCA conducted on the Adriatic basins showed the distinction between the middle Adriatic basin and the rest of the Padano-Venetian district (Additional file $4 \mathrm{~b}$ ). The FCA conducted on the Tyrrhenian basins showed a structure that follows the grouping explained by both the NJ tree and the pair wise multilocus $\mathrm{F}_{\mathrm{ST}}$ values, with a group representing the West Ligurian populations, a group representing the Central Ligurian populations, a group formed by the East Ligurian populations, and 
another one by the Tuscano-Latium populations (Additional file 4c).

The most probable number of $K$ populations in the Bayesian clustering analysis was 5 when applying the " $L(K)$ " method suggested by Evanno et al. [40] (Fig. 2b; Additional file 5). With $K=5$, a population structure with four principal groups was recovered: $(i)$ individuals from the Veneto and Po River populations (pops. 1 to 19) and Central Liguria (pops. 27 to 29); (ii) individuals from the Middle Adriatic populations (pops. 20 and 21); (iii) individuals from West Liguria (pops. 23 to 26); and (iv) specimens from East Liguria (pops. 30 to 33 ) and TuscanyLatium (pops. 34 to 39). The genomes of the first group consisted of two distinct genetic pools.

In order to quantify population genetic structuring within and among populations a hierarchical AMOVA was computed grouping the populations into five groups following the grouping suggested by $\mathrm{F}_{\mathrm{ST}}$ analysis, the FCA, the NJ tree and the Bayesian assignment tests. Twenty-nine percent of the variation occurred among groups, $7.7 \%$ among populations within groups, and $62.8 \%$ of the variation was attributed within populations (Additional file 6). $\mathrm{F}_{\mathrm{IS}}$ values are shown in Additional file 7.

\section{Discussion}

\section{Population structure and phylogeography of the Italian vairone}

Our phylogeographic and population genetic analyses based on eight microsatellite markers identified five principal clusters of populations in the Italian vairone. We used information on the geographic origin of the populations, the population NJ tree, the FCA plots as well as the results from the Bayesian assignment test to infer these groups. We note, however, that - despite of the overall support for this grouping - certain analyses resulted in a somewhat deviating picture. These cases are discussed below.

The most widespread group I corresponds to the Padano-Venetian district and includes populations from two Upper Adriatic basins (pops. 1 and 2) and the Po drainage (pops. 3 to 19). The geographic extension of these populations reflects the expansion of the Po river basin up to the Meso-Adriatic depression, which occurred during the last glacial maximum coinciding with the eustatic sea level regression by $120 \mathrm{~m}[42,43]$. Interestingly, three populations of Central Ligurian basins are also included in this group (pops. 27 to 29), although these rivers drain into the upper Tyrrhenian Sea. This clustering of Central Ligurian populations with those from the Po system in all analyses clearly suggests a limited period of "permeability" of the Apennine barrier, allowing gene flow between the Po drainage and Central
Liguria. Group I was consistently recovered in the STRUCTURE analyses and in the FCA plots. Yet, in the population tree, it did not come out as monophyletic, since another group (group II) was resolved within group I (see below). The population assignment tests with STRUCTURE further indicated that the genomes of group I individuals are composed of two genetic pools. This may be explained by the existence of at least two isolated lineages prior to the last glacial maximum that became admixed secondarily.

Group II includes four populations from West Liguria (pops. 23 to 26) and shows affinities with group I, i.e. the fishes from the Padano-Venetian district. In the population tree, group II was actually resolved within group I populations, while in the Bayesian population assignment tests, group II formed a unique cluster (Fig. 2). It is evident, though, that some individuals show the genotypic signature of group I. This pattern could be the result of introgression of Padano-Venetian genomes from the Central Ligurian populations into an older, isolated western Ligurian stock. Alternatively, the West Ligurian basins might have been colonized directly from the upper reaches of the Po system via river capture, as is indicated by the close genetic affinity of population 18 (river Orba) from the Po system to the geographically close populations of West Liguria (Figs. 1, 2). The individual profile of the West Ligurian populations in the STRUCTURE analyses might then be the result of repeated bottlenecks as a consequence of westward dispersal.

Group III consists of two populations only (pops. 20 and 21) that were sampled at the southern edge of the distribution range of $T$. muticellus in two rivers draining into the Adriatic Sea (Tesino and Burano). These two populations clustered together in all analyses and appeared equidistant from groups I and II, group VI and group V, respectively, in the population tree and the FCA plot (Fig. 2; Additional file 4). The Padano-Venetian ichthyogeographic district, which also comprises the Middle Adriatic basin including rivers Tesino and Burano, has been defined based on the extension of the Po basin during the last glacial maximum due to the lowering of the sea level [12] (Fig. 1c). Now, our new analyses of the Italian vairone contradict the view of a close affinity of the Middle Adriatic populations to the Padano-Venetian ones, but support the existence of an isolated Middle Adriatic stock, instead.

Group IV from East Liguria (pops. 30 to 33) was resolved as separate cluster in the population tree and in the FCA plot. Yet, the Bayesian analyses of population structure suggest its close affinity to populations from the Tuscano-Latium district (group V). An origin of the East Ligurian T. muticellus in Tuscany has already been suggested based on mtDNA markers [17]. 
Group V corresponds to the populations of the Tuscano-Latium district (pops. 34 to 39) that were sampled in the Apennine in the upper reaches of the Ombrone, Albegna and Tevere rivers, which all drain into the middle Tyrrhenian Sea. This group was recovered in the FCA plots and the population NJ tree. In the STRUCTURE analyses, it clusters with group IV individuals. The high levels of genetic similarity between the six Tuscano-Latium populations suggest that the three basins sampled shared contact events. These are likely to have occurred in the upper or middle watercourses, where hydrogeographic structures appear conducive for historical transitory river captures. Because of the large distance between the estuaries of the Ombrone and Albegna rivers to the Tevere river and the bathymetric profile of the Tyrrhenian Sea, a connection via downstream river confluence, e.g. during the last glacial maximum when sea levels were substantially lower than at present, appears highly unlikely.

Previous mitochondrial DNA based studies of the Italian vairone $[17,44]$ identified three distinct clusters, which are, overall, in agreement to the ones identified here. Using a smaller set of samples, Zaccara et al. [17] found a clear separation between T. muticellus populations from Tuscany (group V in our study), East Liguria (group IV) and the Padano-Venetian district (group I). Interestingly, their specimens from Western Liguria (group II) clustered together with populations from the Po drainage, just as they do in our population tree (Fig. 2a). However, neither were Central Ligurian populations included in the study of Zaccara et al. [17] (these belong, according to our new analyses, to group I), nor were the Middle Adriatic populations (our group III) studied. Thus, with 509 specimens from 38 populations covering the species' entire distribution range, the present work is the most extensive phylogeographic study of T. muticellus.

\section{A biogeographic scenario for Italian freshwater fishes}

The vairone has previously been studied in the context of postglacial re-colonization scenarios in and around the Alps (see e.g., $[14,15,17])$. There are several reasons that make this species suitable for phylogeographic research. First, the vairone occurs in all major river systems draining off the Alps (Danube, Rhine, Rhône, Po) as well as in many small rivers draining directly into the Mediterranean Sea. Second, the vairone is restricted to certain habitat types within these rivers, making recent large-scale migrations highly unlikely [45]. Third, in most parts of its distribution range, there is no evidence for humaninduced faunal translocation, so that the species' present population structure should display its phylogeographic history. In the present study, we use the Italian vairone ( $T$. muticellus) as a model to infer the phylogeography of Ital- ian freshwater fish species, suggesting a scenario that might serve as a model for other species as well. Specifically, we were interested in the ways by which the vairone, a reophilic species, was able to colonize different river basins through different routes. This should allow us to suppose recent changes in the shape and connection of the hydrographic basins at regional and local scale.

A first outcome from our study is that the populations of T. muticellus are highly structured and fall into five distinct groups, which correspond to geographic areas and drainage systems (see above). Overall, our analyses highlight the existence of strong barriers between geographic areas and major drainage systems, which is reflected in the discrete clustering of populations according to drainage systems, as well as in the significant $\mathrm{F}_{\mathrm{ST}^{-}}$-values between populations even within drainages (Additional file 2).

In our analyses based on nuclear markers, the Apennine emerges as a strong barrier between populations from PV (pops. 1-19) and TL (pops. 34-39). This is in contrast to previous mtDNA based results. Using the very same samples as we do here, Zaccara et al. [17] found mtDNA haplotypes of Tuscano-Latium origin in the Po basin, pointing to a past connection between these two major ichthyogeographic districts. This discrepancy between nuclear and mitochondrial DNA is best explained by a scenario in which some individuals crossed the watershed from the TL district into tributaries of the Po basin. While the descendant lines kept their TL identity in the mtDNA (due to the clonal mode of inheritance of mtDNA), their original nuclear DNA signature disappeared (due to repeated and unidirectional crosses with PV fish leading to a homogenization of the genome towards the native type). This scenario dates the connection between the Padano-Venetian and the Tuscano-Latium ichthyogeographic district in an epoch ancient enough to maintain the genetic differences in the mtDNA, but not in the microsatellites (dated in 0.5 millions years ago by Stefani et al. [44]). This outcome also illustrates the importance of studying both mtDNA and ncDNA to infer a species' phylogeographic history.

While, with the eight microsatellite markers applied, we could not detect the obviously more ancient introgression event(s) in T. muticellus between the two ichthyogeographic districts, several more recent contacts between vairone populations within the two districts became evident. In the PV district, the contacts between isolated basins, e.g. between the Po drainage (pops. 3-19), the Bacchiglione (pop. 2), and the Tagliamento (pop. 1), were possible during periods of glaciation, when the sea level was markedly lowered (see also Salzburger et al. [15]). During these periods, the estuary of the Po reached the middle Adriatic pit, connecting the rivers of the entire PV 
ichthyogeographic district via downstream river confluence (Fig. 1c). The bathymetric profile of the Adriatic Sea, which is a shallow sea with a gently declining profile, made river confluence possible. The Tyrrhenian Sea, on the other hand, is rather deep and has a much steeper profile, so that downstream river confluence is a rather unlikely cause for the observed gene flow between rivers of the TL district. There, historical connections in the middle and upper courses of the rivers, caused by local plate-tectonic events along the Apennine ridge, are most probably responsible for faunal exchange [46,47]. The genesis and the evolution of the Apennine chain favored such kind of exchange, with a wrinkle structure that caused the formation of valleys parallel to the direction of the mountain chain. On the Tyrrhenian side, rivers follow these valleys for long traits, assuming a trend with a North-South orientation, while, on the Adriatic side, rivers are principally orthogonal to the mountain chain. The closing of these valleys could cause the overflowing with the outlet of a river into those of the adjacent valley [48]. Connections between rivers belonging to different sides of a watershed were also suggested for rivers with terminally aligned traces, such as river Lerone and Orba (see Table 1 and Fig. 1) [48]. Such temporal connections between rivers in the past can also explain the phylogeographic pattern observed in the Ligurian basins, where "passover events" occurred from the PV district along the west side of the Alpine chain (pops. 23-26), and from the TL district along the upper Tyrrhenian slope of the Apennine chain (pops. 30-33). The origin of the Middle Adriatic populations (pops. 20 and 21) remains somewhat elusive.

From our analyses at least four different refugia can be delineated, where Italian vairone populations outlived the last glacial maximum: one for the Upper Adriatic basins, one for the Middle Adriatic rivers, one in the TuscanoLatium area and at least one in (East) Liguria. The areal expansion in the Italian vairone has already been implicated with population bottlenecks (in the refugia) followed by demographic expansions, as a consequence of environmental alterations during these periods [17]. Our new analyses corroborate this view.

The population assignment tests with STRUCTURE indicate the existence of two distinct refugia for the Upper Adriatic basins, since the genomes of the sampled individuals appear admixed from more than one genetic pool. The formation of different genetic pools can be attributed to the cyclic variation of the sea level of the Adriatic Sea during glacial cycles. In periods of maximal glaciation, the Po connected all river systems as far as to the MesoAdriatic depression (see Fig. 1c); during these cold periods, the typical vairone habitat shifted towards lower altitudes, whereas - during interglacial periods - the present situation with many isolated populations was restored
[45]. Several factors may account for the generally high degree of isolation between Italian vairone populations, particularly in the Adriatic drainages. First, suboptimal environmental conditions during cold periods could although allowing for survival of vairone populations have inhibited long distance dispersal, thereby limiting gene flow. Such a situation has been reported for the minnow (Phoxinus phoxinus), another cold-adapted rheophilic freshwater fish species [49]. Second, the sandy substrate on the bottom of the Adriatic Sea, which is where the rivers drained to during glaciation (see Fig. 1c), appears unsuitable for egg deposition by the vairone. Since the vairone requires gravely, shallow and well-oxygenated waters, proper spawning grounds may only have been available in the middle parts of rivers, again limiting dispersal. Finally, the (temporarily) increased salinity levels close to the river mouths could have led to barriers for downward migration for stenohaline species such as the vairone.

\section{Conclusion}

Taken together, the following phylogeographic scenario arises for T. muticellus: an initial T. muticellus stock became isolated from its 'Alpine' allies, possibly triggered by the Mediterranean Salinity Crisis some five million years ago [15]. The Italian vairone survived the various glaciation cycles in several refugia, most likely situated in the Upper Adriatic (groups I and II), the Middle Adriatic (group III), (East) Liguria (group IV) and TuscanoLatium (group V); the latter two show closer affinities (see Fig. 2) and might originate from a common Tyrrhenian stock. This grouping is, overall, in agreement with the two main ichthyogeographic districts, Padano-Venetian and Tuscano-Latium, except for the two populations in the Middle Adriatic, which we identify as additional major district. Although in principle dividing the PV and TL districts, the Apennine barrier was "permeable" at some point, leading to the introgression of mitochondrial haplotypes from Tuscano-Latium into the Po drainage [17]; this can be the result of local events of river capture, as suggested by Ghelardoni [48]. Owing to a more complex phylogeographic history, the T. muticellus stocks in the isolated smaller rivers in Liguria do not form a unique cluster. Populations from East Liguria group with those of the Tuscano-Latium district, whereas stocks from Central and West Liguria show affinities to the Padano-Venetian fishes (note that it is unlikely that this situation is due to recent human-induced faunal introductions in Liguria as suggested by Balma et al. [50], since most of the Ligurian populations do show private genetic signatures). Future studies in other freshwater taxa will now be necessary to evaluate the universal validity of the "vairone scenario" proposed here. 


\section{Additional material}

Additional file 1 Number of individuals (N), number of alleles (Na),
observed heterozygosity (Ho), expected heterzygosity (He) per popu-
lation per locus and mean values, FST values per locus and mean val-
ues of Na, Ho and He across all loci and all populations, excluding pop.
22 (T. souffia).
Additional file 2 Estimate of FST among population (above diagonal)
and Nei's distance (below diagonal).
Additional file 3 Allele frequencies.
Additional file 4 Supplemental Figure.
Additional file 5 Supplemental Figure.
Additional file 6 AMOVA results.
Additional file 7 FIS values.

Authors' contributions

FM, SZ and WS designed the study; FM and FMM carried out the molecular work; FM, FMM and WS performed the analyses. All authors contributed to the preparation of the manuscript. They read and approved the final version.

\section{Acknowledgements}

We would like to thank Giovanni B. Delmastro, Fabrizio Stefani, Eugenio Miotti and Enrico Marconato for providing specimens; Michael Matschiner for help with TANDEM; Carlo Bartolini for comments on the Italian geology; Pascal Vonlanthen and three anonymous reviewers for valuable comments on the manuscript; and Giorgio Binelli for the support with the statistical analyses. This study was supported by grants from University of Insubria to FM and to $\mathrm{SZ}$, the Roche Research Foundation to FMM, and the University of Basel to WS.

\section{Author Details}

'Department of Biotechnology and Molecular Sciences, University of Insubria, via Dunant 3, 21100 Varese, Italy and 2Zoological Institute, University of Basel, Vesalgasse 1, 4055 Basel, Switzerland

Received: 29 December 2009 Accepted: 27 April 2010

Published: 27 April 2010

\section{References}

1. Dynesius M, Jansson R: Evolutionary consequences of changes in species' geographical distributions driven by Milankovitch climate oscillations. Proc Nat Acad Sci USA 2000, 97:9115-9120.

2. Hewitt GM: Post-glacial re-colonization of European Biota. Biol J Linn Soc 1999, 68:87-112.

3. Hewitt GM: The genetic legacy of the Quaternary ice ages. Nature 2000, 405:907-913.

4. Hewitt GM: Some genetic consequences of ice ages, and their role in divergence and speciation. Biol J Linn Soc 1996, 58:247-276.

5. Avise JC, Arnold J, Ball RM, Bermingham E, Lamb T, Neigel JE, Reeb CA, Saunders NC: Intraspecific phylogeography: The mitochondrial DNA bridge between population genetics and systematics. Annu Rev Ecol Syst 1987, 18:489-522

6. Bernachez L, Wilson C: Comparative phylogeography of Neartic and Paleartic fishes. Mol Ecol 1998, 7:431-452.

7. Durand JD, Templeton AR, Guinard B, Imsridou A, Bouvet Y: Nested Clade and Phylogeographic Analyses of the Chub, Leuciscus cephalus (Teleostei, Cyprinidae), in Greece: Implications for Balkan Peninsula Biogeography. Mol Phyl Evol 1999, 13:566-580.

8. Bishop P: Drainage rearrangement by river capture, beheading and diversion. Progress in Physical Geology 1995, 19:449-473.

9. Bãnãrescu P: Vicariance and dispersal in freshwater animals. Hydrobiology 1986, 19:257-268.

10. Bianco PG: Potential role of the paleohistory of the Mediterranean and Paratethys basins on the early dispersal of Euro-Mediterranean freshwater fishes. Ichthyol Explor Freshw 1990, 1:167-184.

11. Bãnãrescu P: Zoogeography of Freshwaters. General Distribution and Dispersal of Freshwater Animals in North America and Eurasia Volume 2 Aula-Verlag, Wiesbaden; 1991

12. Bianco PG: Factors affecting the distribution of freshwater fishes especially in Italy. Cybium 1995, 19:241-259.
13. Reyjol Y, Hugueny B, Pont D, Bianco PG, Beier U, Caiola N, Casals F, Cowx I, Economou A, Ferreira T, Haidvogl G, Noble R, de Sostoa A, Vigneron T, Virbickas T: Patterns in species richness and endemism of European freshwater fish. Glob Ecol Biogeogr 2007, 16:65-75.

14. Gilles A, Chappaz R, Cavalli L, Lörtscher M, Faure E: Genetic differentiation and introgression between putative subspecies of $L$. souffia (Teleostei: Cyprinidae) of the region of the Mediterranean Alps. Can J Fish Aquat Sci 1998, 55:2341-2354.

15. Salzburger W, Branstätter A, Gilles A, Parson W, Hempel M, Sturmbauer C, Meyer A: Phylogeography of the vairone (Leuciscus souffia, Risso 1826) in central Europe. Mol Ecol 2003, 12:2371-2386.

16. Salducci MD, Martin JF, Pech N, Chappaz R, Costedoat C, Gilles A: Deciphering the evolutionary biology of freshwater fish using multiple approaches insights for the biological conservation of the vairone. Conserv Gen 2004, 5:63-77.

17. Zaccara S, Stefani F, Delmastro G: Phylogeographical structure of vairone Telestes muticellus (Teleostei, Cyprinidae) within three European peri-Mediterranean districts. Zoo/ Scr 2007, 36:443-453.

18. Ketmaier V, Cobolli M, De Matthaeis E, Bianco PG: Allozymic variability and biogeographic relationships in two Leuciscus species complexes (Cyprinidae) from Southern Europe, with the rehabilitation of the genus Telestes Bonaparte. Ital J Zool 1998, 65:41-48.

19. Zardoya R, Doadrio I: Phylogenetic relationships of Iberian cyprinids: systematic and biogeographical implications. Proc R Soc Lon B 1998, 265:1365-1372

20. Zardoya R, Doadrio I: Molecular evidence on the evolutionary and biogeographical patterns of European cyprinids. J of Mol Evol 1999, 49:227-237

21. Machordom A, Nicolas Y, Crivelli AJ: Genetic variability and differentiation in Leuciscus (Telestes) souffia. Taxonomic and conservation inferences. Les Comptes Rendus de l'Académie Des Sciences Paris Série Biologies III-Vie 1999, 322:15-28.

22. Crivelli AJ, Bianco PG: Telestes muticellus. IUCN 2009. IUCN Red List of Threatened Species. Version 2009.1 [http://www.iucnredlist.org] Downloaded on 09 June 2009

23. Bianco PG: Mediterranean endemic freshwater fishes of Italy. Biol Cons 1995, 72:159-170

24. Arbocco G: I pesci d'acqua dolce della Liguria. Annali del Museo Civico di Storia Naturale di Genova 1966, 76:137-171.

25. Muenzel FM, Sanetra M, Salzburger W, Meyer A: Microsatellites from the vairone Leuciscus souffia (Pisces: Cyprinidae) and their application to closely related species. Mol Ecol Notes 2007, 7:1048-1050.

26. Matschiner M, Salzburger W: TANDEM: integrating automated allele binning into genetics and genomics workflows. Bioinformatics 2009 25:1982-1983.

27. Dieringer D, Schlötterer C: Microsatellite Analyser (MSA): a platform independent analysis tool for large microsatellite data sets. Mol Ecol Notes 2003, 3:167-169.

28. Rousset F: Genepop'007: a complete reimplementation of the Genepop software for Windows and Linux. Mol Ecol Resources 2008, 8:103-106.

29. Guo SW, Thompson EA: Performing the exact test of Hardy-Weinberg proportion for multiple alleles. Biometrics 1992, 48:361-72.

30. Weir BS, Cockerham CC: Estimating F-Statistics for the analysis of population structure. Evolution 1984, 38:1358-1370.

31. Excoffier L, Laval G, Schneider S: Arlequin (v. 3.0): An integrated software package for population genetics data analysis. Evol Bioinform Online 2005, 1:47-50

32. Peakall R, Smouse PE: GENALEX 6: genetic analysis in Excel. Population genetic software for teaching and research. Mol Ecol 2006, 6:288-295.

33. Saitou N, Nei M: The Neighbor-joining Method: A New Method for Reconstructing Phylogenetic Trees. Mol Biol Evol 1987, 4:406-425.

34. Cavalli-Sforza LL, Edwards AWF: Phylogenetic analysis: models and estimation procedures. American J Hum Gen 1967, 19:233-257.

35. Felsenstein J: PHYLIP. Phylogeny Inference Package (Version 3.2). Cladistics 1989, 5:164-166.

36. Van Dongen S: How should we bootstrap allozyme data. Heredity 1995, 74:445-447.

37. Benzécri JP: L'Analyse de Données, Tome 2, L'Analyse des Correspondances. Dunod, Paris 1973.

38. Belkhir K, Borsa P, Chikhi L, Raufaste N, Bonhomme F: GENETIX 4.02, logiciel sous WindowsTM pour la génêtique des populations. Laboratoire Génome 
Populations, Interactions, CNRS URM 5000 Montpellier: Université de Montpellier II; 2004

39. Pritchard JK, Matthew S, Donnelly P: Inference of Population Structure Using Multilocus Genotype Data. Genetics 2000, 155:945-959.

40. Evanno G, Regnaut S, Goudet J: Detecting the number of clusters of individuals using the software structure: a simulation study. $\mathrm{Mol}$ EcOl 2005, 14:2611-2620.

41. Excoffier L, Smouse E, Quattro JM: Analyses of molecular variance inferred from metric distance among DNA haplotypes: application to human mitochondrial DNA restriction data. Genetics 1992, 131:479-491.

42. Rohling RJ, Fenton M, Jorissen FJ, Bertrand P, Ganssen G, Caulet JP: Magnitudes of sea-level lowstands of the past 500,000 years. Nature 1998, 394:162-165.

43. Waelbroeck C, Labeyrie L, Michel E, Duplessy JC, McManus JF, Lambeck K, Balbon E, Labracherie M: Sealevel and deep water temperature changes derived from benthic foraminifera isotopic records. Quat Sci Rev 2002, 21:295-305.

44. Stefani F, Galli P, Zaccara S, Crosa G: Genetic variability and phylogeography of the cyprinid Telestes muticellus within the Italian peninsula as revealed by mitochondrial DNA. J Zool Syst Evol Res 2004, 42:323-331.

45. Ketmaier V, Bianco PG, Cobolli M, Krivokapic M, Caniglia R, De Matthaeis E: Molecular phylogeny of two lineages of Leuciscinae cyprinid (Telestes and Scardinius) from the peri-Mediterranean area based on cytochrome $b$ data. Mol Phyl Evol 2004, 32:1061-1071.

46. Bartolini C, Pranzini G: Evoluzione dell'idrografia nella Toscana centrosettentrionale. Bollettino del Museo di Storia Naturale della Lunigiana 1988, 6-7:79-83.

47. Cattuto C, Cencetti C, Gregori L: Lo studio dei corsi d'acqua minori dell'Italia Appenninica come mezzo di indagine sulla tettonica del Plio/ Pleistocene. Bollettino Museale Di Storia Naturale Lunigiana 1988, 6 7:7-10.

48. Ghelardoni R: Spostamento dello spartiacque dell'Appennino settentrionale in conseguenza di catture idrografiche. Atti Soc Tosc SC Nat Mem 1958, 65:25-38.

49. Garner P, Clough S, Griffiths SW, Deans D, Ibbotson A: Use of shallow marginal habitat by Phoxinus phoxinus: a trade off between temperature and food? J Fish Biol 1998, 52:600-609.

50. Balma GAC, Bianco PG, Delmastro GB: Specie ittiche d'acqua dolce alloctone ed autoctone nuove per il versante tirrenico della Liguria. Annali del Museo Civico di Storia Naturale di Genova 1989, 87:311-318.

doi: 10.1186/1471-2148-10-111

Cite this article as: Marchetto et al., Phylogeography of the Italian vairone (Telestes muticellus, Bonaparte 1837) inferred by microsatellite markers: evolutionary history of a freshwater fish species with a restricted and fragmented distribution BMC Evolutionary Biology 2010, 10:111

Submit your next manuscript to BioMed Central and take full advantage of:

- Convenient online submission

- Thorough peer review

- No space constraints or color figure charges

- Immediate publication on acceptance

- Inclusion in PubMed, CAS, Scopus and Google Scholar

- Research which is freely available for redistribution

Submit your manuscript at www.biomedcentral.com/submit
C Biomed Central 